\title{
THE SOVIET UNION, THE UN AND WORLD TRADE
}

\author{
Harold Karan Jacobson \\ University of Michigan
}

I

$\mathrm{S}$

INCE 1953 the Soviet Union has radically altered its policy concerning the United Nations' work in the field of international trade. The U.S.S.R. apparently has developed an increased interest in this work and has played a much more active role in it. Soviet representatives now participate in many United Nations' organs which they previously boycotted, and their speeches and actions lack the stridently propagandistic tone which characterized those of Soviet delegates in an earlier period. The U.S.S.R. has even attempted to seize the initiative in some areas through the introduction of new, far-reaching proposals.

These Soviet actions could offer opportunities for expanding the United Nations' work in international trade. They could also threaten Western dominance of this work and American leadership in it, which until recently have been unchallenged. Further, as these actions involve an increased role for communist countries whose attitude toward international trade is different from that of noncommunist countries - particularly from that of the United States - they necessarily will affect the United Nations' work, conceivably modifying its orientation. Therefore, they deserve careful examination and consideration.

Perhaps the new Soviet policy can more easily be understood by viewing it in its historical context. This might help to clarify the policy's underlying rationale and motivations and to facilitate evaluation of its possible impact. For analysis, Soviet policy concerning the United Nations' work in international trade can be divided into three periods. (1) During the world organization's formative stages from 1944 through 1947, the Soviets abstained from most of the UN's activities. (2) During the height of the cold war from 1948 through 1952, the Soviets continued their abstention from the actual work of the UN, but also used the organization as a forum for violent criticism of Western policy. (3) During the period since 1953, the Soviets have assumed a vastly increased role in the UN's activities, although they have not completely abandoned their earlier policies of abstention and criticism.

II

The United Nations' early activities in the field of international trade dealt primarily with the creation of specialized agencies, which it was anticipated would conduct most of the actual work. These activities were based on the assumption that the United Nations' goal should be the expansion of international trade on as free and as multilateral a basis as possible. 
American planners especially held this view, and, because of the dominant position of the United States, they had little difficulty in gaining its acceptance. These Americans thought that the achievement of this goal would not only be valuable in itself, but that it would also be "essential to the attainment of full and effective employment in the United States and elsewhere, to the preservation of private enterprise, and to the success of an international system to prevent future wars." 1 Three specialized agencies were thought to be necessary for the realization of the United Nations' goal: one to aid in stabilizing currencies; another to lend money for reconstruction and development purposes; and a third to regulate commercial policy and work toward the reduction of tariffs and other barriers to trade.

Two of the planned specialized agencies, the International Monetary Fund (IMF) and the International Bank for Reconstruction and Development (IBRD), were created even before the United Nations. Although the Soviet Union did not join either, it did participate in drafting their Charters at the Bretton Woods Conference in 1944 and in earlier informal discussions concerning them. In these negotiations Soviet delegates appear to have had little interest in the broad objectives of the Fund and the Bank. ${ }^{2}$ Instead, they were mainly concerned with matters which would directly affect the U.S.S.R.: the cost of participation; the availability of credits; the extent of the organizations' control over the Soviet economy; and conversely, the extent of Soviet control over the organizations' activities. Soviet representatives raised these same issues in later discussions of the two agencies in the United Nations. ${ }^{3}$ Although concessions have been made to the Soviet position, the organizations' fundamental structures and purposes have never been altered.

An International Trade Organization (ITO) was to have been the third specialized agency in this field. As a result of American initiative steps were taken toward its creation at the first session of the Economic and Social Council (ECOSOC) in the spring of 1946. The U.S.S.R. supported the initial resolution passed then, but did not attend the subsequent conferences in London, Geneva, and Havana. Nor did Soviet delegates partici-

\footnotetext{
1 "Summary of the Interim Report of the Special Committee on Relaxation of Trade Barriers," in Postwar Foreign Policy Preparation, 1939-1945, Department of State Publication 3580, General Foreign Policy Series 15 (1949), p. 622.

'See Raymond F. Mikesell, "Negotiating at Bretton Woods, 1944," in Raymond Dennett and Joseph E. Johnson (eds.), Negotiating with the Russians (Boston: World Peace Foundation, 1951), pp, 101-16.

${ }^{3}$ One instance of this occurred during the discussions of the agreements between the UN and the IMF and the IBRD. Soviet delegates then strongly objected to the special status given these agencies and the lack of UN control over them. See: United Nations, Economic and Social Council, Official Records (5th session), pp. 269-70; United Nations, General Assembly, Official Records, (2nd session, Joint Second and Third Committee), pp. 12-14, 31-32; and United Nations, General Assembly, Official Records (2nd session, Plenary Meetings), pp. 952-53.
} 
pate significantly in ECOSOC's step-by-step discussions of these conferences.

One authority maintains that because of the U.S.S.R.'s failure to participate in the negotiations some of the proposals concerning state-controlled economies were dropped from the ITO, or Havana, Charter and that the sanctions against non-members were reduced. ${ }^{4}$ Neither the Soviet Union's abstention, nor her later attack on the Havana Charter, however, was a basic cause of the instrument's failure to obtain the necessary ratifications. Its nature as a compromise document which fully satisfied no one and the lack of American support was chiefly responsible for this.

There could be several explanations for the Soviet Union's abstention from the United Nations' activities concerning international trade during this early period. The U.S.S.R. could not have been expected to be interested in either their direct or indirect goals. While the UN sought to expand international trade on as free and as multilateral a basis as possible, communist doctrine stressed the necessity of self-sufficiency, and much of the U.S.S.R.'s economic policy had been directed toward this end. ${ }^{5}$ The trade which the Soviet Union engaged in was generally aimed at securing imports necessary to implement economic development programs, or at securing political advantages. Both ends usually can best be achieved through bilateral rather than multilateral trade. Nor could the Soviet Union have been very enthusiastic about preserving private enterprise and maintaining full employment in the United States and other Western countries, two indirect goals which underlay the American desire for expanded multilateral trade.

Even the planned technical work of the United Nations and the specialized agencies could have been of little interest to the Soviet Union, for it had almost no application to a situation where foreign trade is controlled by a state monopoly, as it is in the U.S.S.R. Furthermore, membership in any of the three specialized agencies might have involved some slight degree of outside control over Soviet economic policies and would have required the disclosure of then secret information. Then too, the United Nation's activities with their global orientation might have interfered with attempts to unify the Soviet bloc. The fact that the satellites eventually also withdrew from these activities could be evidence that the Soviet elite thought that such interference might have occurred.

\footnotetext{
${ }^{4}$ Clair Wilcox, A Charter for World Trade (New York: Macmillan, 1949), passim and especially pp. 101-2 and 162-64.

${ }^{5}$ See: Alexander Baykov, Soviet Foreign Trade (Princeton: Princeton University Press, 1946); Harry Schwartz, Russia's Soviet Economy (2d ed.; New York: Prentice-Hall, 1954), chapter 14; Willis C. Armstrong, "The Soviet Approach to International Trade," Political Science Quarterly, LXIII (September, 1948), 368-82; and Michael L. Hoffman, "Problems of East-West Trade," International Conciliation, No. 511 (January, 1957), pp. 259-308, especially pp. 267-70.
} 
It is likely that the U.S.S.R. only participated in the Bretton Woods Conference and other negotiations to maintain the necessary wartime unity and perhaps in the hope of obtaining credits for postwar reconstruction. The development of the cold war made it clear that this hope would not be fulfilled.

\section{III}

The cold war increased in intensity during the second period, from 1948 through 1952, and it appears to have been the dominant factor motivating Soviet policy then. During this period the U.S.S.R. continued to abstain from most of the United Nations' activities designed to expand international trade. The Soviet Union did not participate in the IMF, the IBRD, the interim organizational arrangements established to temporarily work in the area planned for the ITO, or in the technical committees established by the Economic Commission for Europe (ECE) which could have had a significant impact on intra-European trade. But this absention did not preclude an active policy. On the contrary, the U.S.S.R. was extremely active as it constantly used the United Nations as a forum from which to attack Western international trade policies. This attack had three main facets: one centered on the activities of the United Nations and the specialized agencies; a second concerned the policy pursued by the United States and other Western countries of limiting the export of strategic goods to communist countries; and a third, while having the same ultimate target as the second, concentrated on problems of East-West trade in Europe.

The Soviet attack on the Havana Charter illustrates the first facet of Soviet policy. When the report on the recently completed Charter was discussed at the Economic and Social Council's seventh session in the summer of 1948, the Soviet delegate charged that the Havana Conference "had produced no useful results whatever for the development of international trade." " $\mathrm{He}$ argued that the Conference failed because the industrially developed states used it as a device to attempt to impose unfavorable trading conditions on underdeveloped countries, and because the United States used it to assert its interests to the exclusion of those of all others. There had been sufficient conflicts during the negotiations to make these charges have some appeal, and they were repeated by Soviet delegates on several other occasions in the United Nations. This Soviet attack must have exacerbated the inherent conflicts concerning the Havana Charter and probably made its ratification more difficult.

Soviet delegates in the United Nations also attacked the International Monetary Fund and the International Bank for Reconstruction and Development. They alleged that both were "tools" of United States foreign policy, that both discriminated against underdeveloped and Eastern Euro-

${ }^{6}$ United Nations, Economic and Social Council, Official Records (7th Session), p. 322. 
pean countries. ${ }^{7}$ They deplored that the agreements with these agencies gave the UN so little power and argued that the UN should have the right to make recommendations concerning their credit activities so that the alleged discriminations could be corrected.

The U.S.S.R. maintained that it did not participate in the Economic Commission for Europe's technical committees because they did not deal with the "fundamental tasks and aims" assigned them. Soviet representatives held that this was due to Anglo-American policies which sought to "deflect the work of those bodies in such a direction as would answer to their plans for seizing European markets and for subordinating the economy of European countries to the political, military, and strategic interests of those great States." 8

The U.S.S.R., voted against, or abstained on, all United Nations' resolutions dealing with the mechanical problems of international trade on the ground that they violated national sovereignty and were therefore ultra vires. These resolutions concerned the elimination of double taxation, the conclusion of a convention on customs treatment of samples and advertising, and the amelioration of problems involved in the movement of goods and persons across national frontiers. Soviet representatives further refused to take part in the UN's efforts to deal with problems involved in the transport of dangerous goods and attacked these activities, charging that the problems were simply the result of the aggressive Anglo-American rearmament policy.

While Soviet policy in its first facet during the period from 1948 through 1952 attacked the West indirectly by criticizing the United Nations' activities, in its second facet Soviet policy was less circuitous. Starting with the seventh session of the Economic and Social Council in the summer of 1948 and with the third session of the General Assembly that fall, the Soviet Union and the satellites constantly raised the question of "discrimination in international trade." Representatives of these States maintained that the Western controls on strategic exports were the most important discrimination and therefore, the chief factor limiting the expansion of international trade. They argued that such an expansion was not only necessary for reconstruction, but would also facilitate diplomatic and political co-operation. ${ }^{9}$

These arguments were frequently capped with the introduction of resolutions condemning discrimination in international trade. Although phrased in general terms, statements in the debate made it clear that these were

\footnotetext{
${ }^{7}$ See for example United Nations, General Assembly, Official Records (3rd Session, Plenary Meetings), p. 692.

${ }^{8}$ United Nations Document E/ECE/SR. 3/4, Corr. 3, p. 2.

- For example, see United Nations Document E/ECE/SR. 4/12, pp. 8-9.
} 
aimed at the United States and its principal allies. ${ }^{10}$ None of the resolutions were ever adopted. However, the United Nations often did adopt resolutions expressing the hope that trade would be expanded, and these usually stated that this should be done on a nondiscriminatory basis. But these resolutions were carefully phrased so that they could not constitute a condemnation of the Western controls on strategic exports.

In the third facet of their policy the Soviets were more successful. Although the ultimate target again seems to have been the controls on the export of strategic goods, the immediate goal was the creation of special machinery in the Economic Commission for Europe to promote intraEuropean trade. This facet of Soviet policy was inaugurated at ECE's third session in the spring of 1948 when the U.S.S.R. proposed that ECE establish a committee to study and make recommendations on steps to facilitate an expansion of trade between countries of Europe and also between Europe and other areas; methods of obtaining long- and short-term credit for use in developing European trade; and means of eliminating the after-effects of the war. ${ }^{11}$ This proposal fell on fertile ground, for many, including ECE's Executive Secretary, Mr. Gunnar Myrdal, thought that a revival of East-West trade would at least partially solve Europe's economic problems.

The United States and the United Kingdom, however, were skeptical. They feared that the proposal might simply be an appeal for aid for Eastern Europe and an attempt to have the ECE condemn the recently adopted United States' policy of unilaterally determining the allocation of relief and reconstruction aid. The fact that it was linked with another proposal providing for the creation of a subcommittee "for the Maintenance and Development of those Branches of Industry which are most essential for the Economy of European Countries" ${ }^{12}$ strengthened their doubts. Despite the Anglo-American caution, there was sufficient support in the Commission to inaugurate negotiations on the establishment of a committee for the development of trade.

The Soviets pursued three main tactics in these negotiations, which continued through the summer of $1949 .{ }^{13}$ First, they tried to link the question of intra-European trade with that of economic development. They initially insisted, as they had at ECE's third session, that two committees should

\footnotetext{
${ }^{10}$ Amazasp A. Arutiunian's statement at the General Assembly's third session is an example of this: United Nations, General Assembly, Official Records (3rd session, Second Committee), pp. 213-23.

${ }^{11}$ United Nations Document E/ECE/79, Appendix B.

${ }^{12}$ Ibid.

${ }^{13}$ The negotiations ocurred in ECE's ad hoc Committee on Industrial Development and Trade (United Nations Document E/ECE/83); in ECE's fourth session (United Nations Documents E/ECE/SR. 4/9, 10, 11, 12, and 25) and in ECOSOC's ninth session (United Nations, Economic and Social Council, Official Records [9th session], pp. 70-114).
} 
be established, one on trade and the other on economic development. The United States and the United Kingdom, on the other hand, initially contended that ECE's existing technical committees could perform all the proposed functions. Finally it was agreed that one new committee should be established. Most members of ECE agreed with the Anglo-American position that this committee's mandate should be limited to trade. The U.S.S.R.'s proposal that it "should also study and make recommendations on measures promoting restoration and development of the industries of European countries, especially those which have suffered from war and occupation" failed, receiving support only from the Soviet bloc. ${ }^{14}$

Secondly, the U.S.S.R. attempted to secure full voting privileges for certain states which had consultative status with ECE: Albania, Bulgaria, Finland, Hungary, Italy, and Rumania. The Soviet proposals were discriminatory as they ignored four other states who also had similar status with ECE: Austria, Ireland, Portugal, and Switzerland. Had these proposals been adopted the U.S.S.R. would have controlled ten (or nine after Yugoslavia's expulsion from the Cominform) of the twenty-four possible members. Assuming that all of the eligible states might not have participated and that the Scandinavian states would have been reluctant to oppose the Soviet Union, the U.S.S.R.'s dominance would have been assured.

Finally, on every possible occasion during the negotiations, either the Soviet Union or one of the satellites attacked the Western controls on the export of strategic goods. For example, the Soviet Union proposed that the ad hoc group which ECE appointed to explore the possibility of establishing a trade committee "pronounce itself against the prohibitions and limitations imposed on trade of the countries of Western Europe by the Marshall Plan." ${ }^{15}$ This suggestion was rejected, as were all similar proposals. Only the Soviet bloc supported them.

The U.S.S.R.'s abstention on the final vote on the terms of reference of ECE's Committee on the Development of Trade, as it was named, reflected the general Soviet defeat. These terms largely represented the AngloAmerican position.

The Committee on the Development of Trade held two meetings in 1949, even before its terms of reference were finally approved. ${ }^{16}$ Despite Soviet protests these meetings were held in private. The two sessions ended in deadlock. The West held that the Committee's first task should be to establish a clear conception of the goods available for East-West trade and the demand for these goods. Western statesmen argued that only on the basis of such a preliminary exchange of information could plans be evolved

\footnotetext{
${ }^{14}$ United Nations Document E/ECE/83, p. 4.

${ }^{15}$ Ibid., p. 5.

${ }^{16}$ See United Nations Document E/ECE/114/Rev. 1.
} 
for increased trade. As the Soviet bloc at that time was not willing to supply any information beyond that already published, the West felt that there was no point to continuing the discussions.

On the other hand, the Soviets maintained that the export licensing policy practiced by the Western countries rendered any effort to develop East-West trade futile. The U.S.S.R. and the satellites argued that the Committee's prime function should be to adopt resolutions against this alleged discrimination and to force the states involved to end it. As the West was not willing to do this, the deadlock was complete.

The most significant decisions resulting from these two sessions of the Committee on the Development of Trade were those which gave the Executive Secretary power to conduct studies and other activities exploring methods to expand East-West trade. On this basis Mr. Gunnar Myrdal continued work in this area even though no further meetings of the full Committee were held until 1954.

Mr. Myrdal first circulated memoranda containing suggestions for a multilateral trade agreement. ${ }^{17} \mathrm{He}$ thought that an agreement might include: (1) relatively long-term purchasing agreements by Western countries for cereals (and possibly other goods) from Eastern countries; (2) a Western commitment that the proceeds of these sales could be used for the purchase of goods on lists which would be based on mutual agreement; and if desired, (3) arrangements for increased flexibility in payments. No government opposed these suggestions.

Therefore, in the fall of 1950, Mr. Myrdal convened an ad hoc meeting to explore the possibility of implementing his proposals. ${ }^{18}$ Little came of this conference, and Mr. Myrdal himself characterized the results as "disappointing." 19 The Soviets blamed the failure on the Western European countries, alleging that they could not guarantee the delivery of goods because of the controls on strategic exports. The West, on the contrary, felt that the real responsibility lay with the countries of Eastern Europe which they claimed could not supply the needed grain.

The following year Mr. Myrdal organized an informal meeting of trade experts from Denmark, France, Hungary, Poland, the U.S.S.R., and the United Kingdom in the hope - which proved illusory - that some trade agreements might eventually develop from bilateral talks started there. Later, he decided that it might be useful to have another consultation of trade experts in September, 1952, and circulated an aide memoire suggesting this. Although fourteen Western countries replied affirmatively, the Soviet bloc failed to reply. Therefore, the conference was not held.

\footnotetext{
${ }^{17}$ Ibid., p. 57.

${ }^{18}$ See United Nations Document E/ECE/127-H.

${ }^{19}$ United Nations Document E/ECE/SR. 6/1, p. 5.
} 
The onus for the breakdown of the talks fell clearly on the Soviet bloc. It was apparent that the U.S.S.R. and the satellites were not interested in increasing trade within the existing framework. The period closed with East-West trade at an extremely low level and with a complete deadlock on these questions in the Economic Commission for Europe. What constructive work was done by the United Nations concerning international trade was the result of co-operation solely among the non-Soviet states. Soviet abstention from these activites was complete.

\section{IV}

As the Economic Commission for Europe had been the focus of the deadlock between East and West on international trade, it was a logical place for the Soviets to introduce their new policy of co-operation, and this new policy has probably had its greatest impact in ECE. However, the new Soviet policy has had broader aspects as well. It has also been oriented toward the trade problems of underdeveloped countries and toward the organization of global machinery to facilitate the conduct of international trade.

The first evidence of the change in Soviet policy came January 17, 1953, when the U.S.S.R. finally replied to Mr. Myrdal's aide memoire of the previous fall suggesting another trade consultation. The U.S.S.R. agreed to participate, and this signaled the end of the deadlock in ECE. As a result, a meeting of trade experts was held in August, 1953. The technique of simultaneous bilateral negotiations was given its first large-scale test at this meeting. The ECE Secretariat had long advocated this device as a possible means of improving the system of strictly bilaterally negotiated trade agreements which prevailed in postwar Europe. During these bilateral talks Soviet representatives are said to have adopted a "business is business" attitude and apparently never mentioned the export restrictions. ${ }^{20}$ The meeting was generally judged a success, and it was agreed that another similar session should be held in 1954. Since then such consultations have been a regular feature of ECE's work.

Further evidence of the new Soviet policy of co-operation was given at ECE's ninth session in the spring of 1954 . The Soviet representative announced then that his government would participate in all of the Commission's technical committees, ${ }^{21}$ and by the end of the year this promise had been fulfilled. This vastly increased the potential range of ECE's activities.

The Soviet delegate also proposed at ECE's ninth session that the Committee on the Development of Trade convene in 1954 and consider "(a)

\footnotetext{
${ }^{20}$ Hoffman, op. cit., p. 296. See also the Executive Secretary's report: United Nations Document E/ECE/166.

${ }^{21}$ United Nations Document E/ECE/SR. 9/2, p. 11.
} 
the removal of obstacles to foreign trade; (b) the conclusion of long-term and multilateral trade and payments agreements; (c) the convening of meetings of experts on trade questions; (d) the arranging of meetings of representatives of business circles; (e) the publication of a special bulletin on foreign trade questions; (f) the organization of international trade fairs." 22 In the debate, this proposal was used as a springboard for an attack on the Western restrictions on trade with communist countries. Despite this, the Soviet record in the 1953 trade consultation and the subject's natural appeal provided sufficient inducement for most Western delegates, and the Soviet resolution was adopted in a modified form. ${ }^{23}$

The Committee on the Development of Trade convened in the fall of 1954, and this group has also held regular meetings since then. It has recently concentrated primarily on four issues concerning East-West trade: (1) long-term trade agreements, (2) improvement of payments arrangements, (3) standardization of general conditions of sale, and (4) arbitration of commercial disputes. Although few concrete accomplishments appear to have resulted from the Committee's discussions, the ground work possibly has been laid for later action.

While Soviet representatives participated actively and constructively in these meetings of the Committee on the Development of Trade and in the meetings of ECE's subsidiary organs generally, in ECE's public, plenary sessions they continue their attacks on the West's control of strategic exports. ${ }^{24}$ In terms of formal impact - resolutions adopted by ECE - these attacks have had no effect. Only the Soviet bloc supported the U.S.S.R.'s proposals that ECE condemn the Western controls. However, the informal, psychological impact of the Soviet attack has probably been greater. It certainly must have contributed to the growing feeling in Western Europe against the restrictions.

The new Soviet policy in ECE reached a climax in the spring of 1956 at the eleventh session when the U.S.S.R. proposed that negotiations be initiated concerning an all-European economic agreement; the creation of an ECE subsidiary organ to deal with peaceful uses of atomic energy; and the elaboration of recommendations for developing business contacts between countries of Eastern and Western Europe. ${ }^{25}$ The Commission did not act

\footnotetext{
${ }_{22}$ United Nations Document E/ECE/SR. 9/6, p. 20.

${ }^{23}$ See United Nations, Economic and Social Council, Official Records (18th session), Supplement No. 3, "Economic Commission for Europe: Annual Report," p. 20.

${ }^{24}$ See the speech of the Soviet representative at ECE's tenth session in the spring of 1955 (United Nations Document E/ECE/SR. 10/8, pp. 4-6) and the proposal he made then (United Nations, Economic and Social Council, Official Records [20th session], Supplement No. 3, "Economic Commission for Europe: Annual Report," p. 44). See also the Soviet delegate's speech at ECE's eleventh session (United Nations Document E/ECE/SR. 11/5, pp. 5-13.

${ }^{25}$ United Nations Document E/ECE/243.
} 
substantively on the first two proposals; it merely asked the U.S.S.R. to expand them and the Executive Secretary to solicit member states' views. ${ }^{26}$ These proposals were introduced and discussed again at ECE's twelfth session in May, 1957,27 but the results were similarly inconclusive. The U.S.S.R.'s third proposal concerning business contacts was adopted at ECE's eleventh session, but in a broadened form covering increased contacts generally.

One of the motivations responsible for the new Soviet proposals apparently was the perennial desire to attack the strategic export ban. In introducing them, the Soviet representative stated that further efforts were needed for the "speedy elimination of artificial barriers" to East-West trade. $^{28}$ Another motivation may have been a desire to block progress toward integration in Western Europe. The first two Soviet proposals cover exactly the same areas as the treaties for a European Economic Community and a European Atomic Energy Community, and they must have been posed as alternatives to these treaties.

A second, broader aspect of the new Soviet policy concerns the trade problems of underdeveloped areas. In the past few years the U.S.S.R. has made a major effort to woo the underdeveloped countries and as a part of this strategy trade between the Soviet bloc and these countries has been vastly increased. The Soviets used the UN in 1954 as a convenient forum from which they could announce their new willingness (and ability) to engage in trade. ${ }^{29}$ Soviet representatives stated that the U.S.S.R. would be willing to supply industrial equipment and machinery to the underdeveloped countries on the basis of long-term agreements. They offered extremely attractive credit arrangements, including the possibility of repayment in local currencies. These offers had considerable appeal in view of the difficulties the underdeveloped countries faced in obtaining needed equipment, and they were the prelude to several trade agreements.

In 1954 the Soviet Union also supported the Economic and Social Council's decision to establish a Commission on International Commodity Trade. The underdeveloped countries had wanted to establish such a commission for sometime, but their efforts had been blocked by the developed countries of the West, who continued their opposition even after the Commission's creation. ${ }^{30}$ Generally, the U.S.S.R. has been more sympathetic

\footnotetext{
${ }^{26}$ See United Nations, Economic and Social Council, Official Records (22nd session), Supplement No. 6, "Economic Commission for Europe: Annual Report," pp. 32-33. ${ }^{27}$ New York Times, May 4, 1957, p. 3.

${ }^{28}$ United Nations Document E/ECE/SR. 11/5, p. 10.

${ }^{29}$ See the Soviet delegates' speeches at ECAFE's tenth session (United Nations Document E/CN. 11/389, pp. 54-56), and ECOSOC's seventeenth session (United Nations, Economic and Social Council, Official Records [17th session], pp. 231-32).

${ }^{30}$ Belgium, France, Norway, the United States, and the United Kingdom all vored against the establishment of this Commission (United Nations, Economic and Social Council, Official Records [17th session], p. 234).
} 
than the West to the underdeveloped countries' position concerning problems of commodity trade. During this same period the Soviet Union also began to participate in the United Nations Expanded Program of Technical Assistance, and this further contributed to the growing rapprochement on economic questions between the U.S.S.R. and the underdeveloped countries.

In addition, the U.S.S.R. developed a new propaganda attack in the UN oriented toward the underdeveloped areas. This attack's theme was that the restrictions on the export of strategic goods - particularly those against China - interfered with the growth of the underdeveloped countries' economies. Arguing from this premise, Soviet delegates introduced new resolutions condemning discrimination in international trade. These were passed, but only after they were modified so as not to imply a condemnation of Western policy. ${ }^{31}$

On balance, in terms of the growing trade between the underdeveloped countries and the Soviet bloc and the increasing alignment of the Soviet bloc and the underdeveloped countries in the United Nations' debates on international trade, this second aspect of the new Soviet policy seems to have been relatively successful.

The third aspect of the new Soviet policy concerns global machinery to facilitate the conduct of international trade. The West had hoped that the International Trade Organization would provide the basic organizational structure in this area, but the Havana Charter never came into force, and as time passed the West was forced to develop other machinery. On a global level the General Agreement on Tariffs and Trade (GATT - the one concrete product of the negotiations concerning the drafting of the ITO Charter) was expanded into a semi-permanent organization. ${ }^{32}$ This arrangement, however, was not completely satisfactory. Its apparent temporary nature caused uncertainty in some states, and its structure was weak. Consequently it was proposed that an Organization for Trade Co-operation (OTC) be created, using the GATT structure as a base. In the spring of 1955 the text of the OTC agreement was completed and submitted to the members of GATT for ratification. According to it, states could not join OTC unless they accepted the obligations of GATT and were accepted by GATT. This rule, at least for the present, would preclude the Soviet Union and the satellites. ${ }^{32 \mathrm{a}}$ Some of the new Soviet actions might therefore be interpreted as countermoves against this exclusion.

${ }^{81}$ See Economic and Social Council Resolution $531 \mathrm{C}$ (XVIII) and General Assembly Resolution 830 (IX).

32 This development is described in Raymond Vernon's "Organizing for World Trade," International Conciliation, No. 505 (November, 1955), pp. 163-222; and in two reports by the United Nations Secretariat: United Nations Documents E/2737 ("The Quest for Freer Trade"), and E/2897.

${ }^{32 n}$ Whether it will continue to do so in the future is problematical. Poland recently applied for membership in GATT, and its application will be considered at GATT's next ses- 
Certainly this interpretation partially explains a series of Soviet actions inaugurated at the Economic and Social Council's twentieth session in the summer of 1955. The Soviet representative announced then that the U.S.S.R. was willing to support the Havana Charter and proposed that the Council appeal to member states to ratify the Charter. ${ }^{33}$ At the same time, he stated that GATT would never be a suitable agency for the conduct of trade negotiations on a global level because its membership was limited. As he also claimed that further efforts were required to eliminate export restrictions, it seems reasonable to infer that this action was in addition designed to provide a new vehicle through which to attack the strategic export controls. Although the Soviet proposal was not accepted, two resolutions were adopted at the twentieth session concerning the organization of machinery to facilitate world trade. ${ }^{34}$ They insured that the subject would be discussed again the following year and asked the Secretary-General to develop relevant studies meanwhile.

When discussion resumed at ECOSOC's twenty-second session, the Soviet Union dropped her appeal for ratification of the Havana Charter and proposed instead that an ad hoc committee be established to study and make recommendations on the creation of an international organization for trade co-operation. ${ }^{35}$ The Soviet delegate held that such an organization should be open equally to members and non-members of the United $\mathrm{Na}$ tions and that it should work for the elimination of all discriminatory restrictions in trade. ${ }^{36}$ Similar proposals have been made since then by Yugoslavia and Poland at the eleventh session of the General Assembly last winter and by the then Foreign Minister Demitri Shepilov in a speech before the Supreme Soviet February 12, 1957. Both of these latter proposals also involved the convocation of a world economic conference.

To date none of these suggestions have been accepted, and at the General Assembly's eleventh session when the Polish-Yugoslav proposal was put in juxtaposition to a Western proposal favoring the ratification of OTC, the latter won easily. But the Soviet Union and the satellites have set forth an alternative concept of machinery to facilitate the conduct of world trade which will certainly be raised and discussed again. This alterna-

sion in October, 1958. If the application is accepted it will be the first time that this privilege has been extended to a communist state, for although Czechoslovakia is a member of GATT, it joined before falling completely under communist control. The Polish application might be a test case, and if successful, it could conceivably be followed by one from the U.S.S.R. For this reason, and because it involves admitting a communist state to what previously was a "private-enterprise club," the Polish application has profound implications for GATT.

${ }^{33}$ United Nations, Economic and Social Council, Official Records (20th session), pp. 76-77.

${ }^{34}$ Economic and Social Council Resolutions $579 \mathrm{~A}(\mathrm{XX})$ and 592 (XX).

${ }^{35}$ United Nations Document E/L. 734.

${ }^{36}$ United Nations, Economic and Social Council, Official Records (22nd session), p. 104. 
tive remains a threat to the West should its efforts to construct machinery in this area falter; and the longer the ratification of OTC is postponed, the greater this threat becomes.

The type of organizational machinery concerning international trade that the U.S.S.R. would prefer - and probably would work toward if given the opportunity - can perhaps be seen by examining a second course of action which the Soviets pursued as a part of this aspect of their new policy. This course of action was introduced at the ninth session of the Economic Commission for Europe in the spring of 1954 when Czechoslovakia, with strong Soviet support, proposed that ECE explore the possibility of extending the technique of simultaneous bilateral negotiations to an interregional level..$^{37}$ Despite skepticism, the Czechoslovakian resolution was adopted in a modified form, and similar resolutions were later passed in ECOSOC and ECAFE. Finally, at the insistence of the Soviet bloc, in 1955 ECOSOC authorized the convocation of the interregional trade negotiations. ${ }^{38}$ As yet no such negotiations have been held; however, they remain a possibility and an alternative approach to the problems of international trade.

\section{$\mathrm{V}$}

The change in Soviet policy in relation to the United Nations' work concerning international trade in part merely reflects developments in the economies of the Soviet Union and the satellites. The fundamental problem of the Eastern economies in the early postwar years was reconstruction, and the United Nations as it developed could contribute little to this. Furthermore, the Soviet elite apparently wanted the satellites to reorient their economies internally by giving greater emphasis to industrial production, and externally by directing their foreign trade more toward one another and toward the U.S.S.R. Participation in the United Nations' activities would not have aided in achieving this; it might even have interfered. By 1953, however, the Eastern economies had recovered from the war and had made substantial further progress. The desired reorientation had also occurred. ${ }^{39}$ The U.S.S.R. and the satellites were then free to concentrate on other objectives and to expand their international trade on a new basis if they desired.

The decision to take advantage of this opportunity may have been prompted primarily by internal considerations. The willingness to engage in trade and to co-operate in this area of the United Nations' work, may simply have been a product of the new Soviet elite's desire to consolidate its power through raising living standards. The composition of the expanded

\footnotetext{
${ }^{37}$ United Nations Document E/ECE/SR. 9/10, pp. 8-12.

${ }^{38}$ Economic and Social Council Resolution $579 \mathrm{~B}$ (XX).

${ }^{39}$ See United Nations, Economic Commission for Europe, Economic Survey of Europe in 1954 (Geneva, 1955), chaps. 2, 3, and 5.
} 
trade indicates that this probably was a factor. This new policy may also have been chosen as a means of reducing world tensions and thereby allowing the new elite to concentrate more on internal problems.

But it is possible that the Soviet Union would have taken advantage of the new opportunity and changed its policy in the UN even if Stalin had lived, and without reference to internal considerations. Indeed, the first indication of the change in ECE came before Stalin's death. Further, the change was to some extent foreshadowed by the events of the Nineteenth Congress of the Communist Party of the Soviet Union and by Stalin's major address there. If Soviet policy through 1952 can be interpreted largely as an attack on the West, this attack had failed. While Soviet speeches and proposals had some effect at first, by 1952 their hollowness had been exposed. New tactics were also needed after 1952 because the situation had changed. Through the Organization for European Economic Co-operation, the European Coal and Steel Community, and other devices, Western Europe moved, however fitfully, toward integration. The West also progressed in the construction of global machinery to facilitate the conduct of trade. As neither development included the Soviet bloc, it seems plausible to assume that the U.S.S.R. should attempt countermoves. Thus the new Soviet policy may simply be a continuation of the older attack on the West through new, more subtle means in a new situation.

While new targets have been added to the Soviet attack - integration in Western Europe and GATT and OTC - the prime target remains the West's ban on strategic exports. On the surface it appears that the Soviet Union desires very much to eliminate this ban. However, while Soviet representatives constantly criticize the ban on strategic exports, they also point out that it has had no effect on the economic growth of the Soviet Union and the satellites. Although their contention would be difficult to substantiate, it is possible that the strategic export ban may have speeded the development of certain aspects of the Eastern economies by forcing the Soviets to develop internal sources of supply. When the ban was relaxed in 1954 the Eastern countries did not immediately purchase significant quantities of most of the goods taken off the controlled list. ${ }^{40}$ Perhaps then there is a deeper motivation for this Soviet attack, which might also yield a more comprehensive explanation for Soviet policy. It may be that the Soviet Union attacked the strategic export ban as much from a desire to exacerbate relations among Western states, as from a desire to eliminate the prohibition, and that this desire to increase tensions in the West is the motivation for all of Soviet policy in the UN concerning international trade.

\footnotetext{
${ }^{40}$ See United Nations, Economic Commission for Europe, Economic Bulletin for Europe, VIII (August, 1956), pp. 48, 56-59. Of course this may merely mean that the relaxation was carefully planned so as not to include goods which the East actually desired, as Soviet representatives have frequently charged.
} 
If it is, Soviet policy has frequently achieved its objective, and the recent changes in this policy enhance the possibility of its continuing to do so.

At the same time, the new Soviet policy has resulted in increased trade between the Soviet bloc and some Western countries and has allowed the UN (especially ECE) to expand its work. This is no doubt immediately important, but its long-range significance is questionable. There is little evidence that communist theories concerning the role of external tradeat least with noncommunist countries - have changed. Furthermore, although the Soviet Union has increased its participation in the United Nations, it has not been willing to join the IMF, the IBRD, GATT, or OTC, and has not significantly changed its narrow definition of national sovereignty concerning the UN's more technical activities. The activities which the Soviet Union has participated in generally have been conducted on a different basis from that originally planned for the UN. They have been, as in ECE, more oriented toward bilateralism than multilateralism, and although Soviet representatives are now less forceful in asserting the superiority of the former technique, their practice is evidence of their continuing preference.

If the Soviet Union expands its role in the United Nations' activities in relation to world trade, a greater shift in the direction of bilateralism will probably result. The U.S.S.R.'s actions and the alternatives it currently poses imply this. It may be, as some have suggested, that the goal of multilateralism as envisaged by the United Nations' planners was inappropriate for the conditions of the mid-twentieh century. ${ }^{41}$ Continuing pressures against this goal from the underdeveloped countries and the countries with advanced welfare-type economies, as well as from the Soviet bloc, indicate that it was. Still, the basic values of multilateralism have not changed, and they remain valid for the West. The challenge presented by the Soviet alternatives is therefore one that should be met, and it has been to date. To continue to meet it, the West will require a policy equally as active and flexible as the U.S.S.R.'s.

\footnotetext{
${ }^{4}$ See Leicester Webb, "The Future of International Trade." World Politics, V (July, 1953), 423-42.
} 